\title{
Discussion on the selection of effect size in meta-analysis
}

\author{
Jiangfeng $\mathrm{Wu}^{1}{ }^{\wedge}$, Xiaoyun Wang ${ }^{2}$, Fang $\mathrm{Xie}^{2}$ \\ ${ }^{1}$ Department of Ultrasound, The Affiliated Dongyang Hospital of Wenzhou Medical University, Dongyang, China; ${ }^{2}$ Department of Nephrology, \\ The Affiliated Dongyang Hospital of Wenzhou Medical University, Dongyang, China \\ Correspondence to: Jiangfeng Wu. Department of Ultrasound, The Affiliated Dongyang Hospital of Wenzhou Medical University, No. 60 Wuning \\ West Road, Dongyang 322100, China. Email: wjfhospital@163.com. \\ Comment on: Zhao G, Zhang Y, Liu C. The effect of health education on the quality of life of postoperative patients with gastric cancer: a systematic \\ review and meta-analysis. Ann Palliat Med 2021;10:10633-42.
}

Submitted Dec 03, 2021. Accepted for publication Feb 03, 2022.

doi: 10.21037/apm-21-3608

View this article at: https://dx.doi.org/10.21037/apm-21-3608

We read with great interest the recent published study by Zhao and colleagues entitled "The effect of health education on the quality of life of postoperative patients with gastric cancer: a systematic review and meta-analysis" (1). They performed a systematic review and meta-analysis to assess the effect of health education on postoperative quality of life in patients with gastric cancer and confirmed that health education can significantly improve patients' quality of life. We appreciate Zhao and colleagues for the valuable work, however, after a careful learning of the literature, we would like to pay attention to some important missing aspects in the study.

Concerning the effect size in the study, the odds ratio (OR) was used when the scores of quality of life and physical, role, emotional, cognitive, and social function were compared between health education group and control group. However, the scores were continuous variable, and mean difference (MD) should be applied when comparison was performed between health education group and control group. Actually, MD is showed in every forest plot in this meta-analysis and OR is suitable for binary variable (2). Moreover, in the method section, sensitivity analysis was introduced. But, in this meta-analysis, results of the sensitivity analysis were not reported in the main text. Therefore, we believe that this study is required to further revise.

We make these comments only to recommend that the authors of similar such studies may consider these comments.

\section{Acknowledgments}

Funding: None.

\section{Footnote}

Provenance and Peer Review: This article was a standard submission to the journal. The article did not undergo external peer review.

Conflicts of Interest: All authors have completed the ICMJE uniform disclosure form (available at https://apm. amegroups.com/article/view/10.21037/apm-21-3608/coif). The authors have no conflicts of interest to declare.

Ethical Statement: The authors are accountable for all aspects of the work in ensuring that questions related to the accuracy or integrity of any part of the work are appropriately investigated and resolved.

Open Access Statement: This is an Open Access article distributed in accordance with the Creative Commons Attribution-NonCommercial-NoDerivs 4.0 International License (CC BY-NC-ND 4.0), which permits the noncommercial replication and distribution of the article with the strict proviso that no changes or edits are made and the original work is properly cited (including links to both the formal publication through the relevant DOI and the license). See: https://creativecommons.org/licenses/by-nc-nd/4.0/.

^ ORCID: 0000-0002-5036-799X. 


\section{References}

1. Zhao G, Zhang Y, Liu C. The effect of health education on the quality of life of postoperative patients with gastric cancer: a systematic review and meta-analysis. Ann Palliat

Cite this article as: Wu J, Wang X, Xie F. Discussion on the selection of effect size in meta-analysis. Ann Palliat Med 2022;11(2):969-970. doi: 10.21037/apm-21-3608
Med 2021;10:10633-42.

2. Wu J, Jin $Y$, Sun $X$. Is magnetic resonance elastography superior to transient elastography for the diagnosis of liver fibrosis? Ann Palliat Med 2021;10:12917-8. 